\title{
PENINGKATAN AKTIVITAS DAN HASIL BELAJAR MAHASISWA PADA MATA KULIAH ANATOMI TUMBUHAN MELALUI MODEL PEMBELAJARAN KOMPARASI YANG BERBASIS LESSON STUDY
}

\author{
Nur Rokhimah Hanik dan Sri Harsono \\ Pendidikan Biologi FKIP Universitas Veteran Bangun Nusantara Sukoharjo \\ E-mail: nurhanik03@gmail.com
}

\begin{abstract}
This study aims to improve the activity and results of student learning in the subject of Anatomy Plant through a comparative study model based lesson study. The method used is classroom action research with 4 cycles. Samples used in this study is the third semester students of regular education courses Biology FKIP Veteran Bangun Nusantara University Sukoharjo force 2012/2013 as many as 24 people. The study began in November 2013 and April 2014. The learning activities were observed in the form of discussion and presentation activities, while learning outcomes measured were the post-test results after completion of the learning process of each cycle. Data analysis techniques with comparative descriptive, comparing the results of learning and learning activity cycle with the cycle I to IV. From the results of this study concluded that the average post-test or study results from Cycle I to IV increased starting 3.47, 3.72, 3.73 and 3.85 , though in terms of learning activities is still not satisfactory because it only categorized quite active for the first cycle to the active cycle III and cycle IV.

Keywords: Model Comparison learning, learning activities, learning outcomes.
\end{abstract}

Proses pembelajaran akan terjadi manakala terdapat interaksi atau hubungan timbal balik antara peserta didik dengan lingkungannya dalam situasi edukatif untuk mencapai tujuan yang telah ditetapkan. Hubungan timbal balik ini merupakan syarat terjadinya proses pembelajaran yang di dalamnya tidak hanya menitikberatkan pada transfer of knowledge, dan transfer of value. Transfer of knowledge dapat diperoleh peserta didik dari media- media belajar seperti buku, majalah, internet, guru, dan sumber-sumber lain yang dapat menambah pengetahuan siswa. Akan tetapi transfer of value hanya akan diperoleh siswa melalui guru/dosen yang menanamkan sikap dan nilai suatu materi dengan melibatkan segisegi psikologis dari guru dan siswa.

Guru adalah faktor penentu keberhasilan proses pembelajaran yang berkualitas. Sehingga berhasil tidaknya pendidikan mencapai tujuan 
selalu dihubungkan dengan kiprah para guru. Oleh karena itu, usahahendaknya dimulai dari peningkatan kualitas guru. Guru yang berkualitas diantaranya adalah mengetahui dan mengerti peran dan fungsinya dalam proses pembelajaran.

Menurut Djohar (1985: 8) menyatakan bahwa guru/dosen mempunyai dua fungsi yaitu fungsi instruktur dan fungsi pendidik. Sebagai instruktur, guru/dosen harus memberikan pedoman belajar yang jelas bagi siswa/mahasiswa, memberi petunjuk, mengarahkan, mengkondisikan belajar, serta menyediakan perangkat kerja yang mungkin diperlukan dalam kegiatan belajar. Sedangkan sebagai pendidik, guru/dosen harus mampu melihat atau mendeteksi kelemahan mahasiswa/ siswa, menolong mahasiswa/siswa yang memerlukan bantuan, memberikan mengevaluasi dan menilai keberhasilan mahasiswa/siswa, serta mampu memberikan remediasi atas kekurangan-kekurangan mahasiswa/ siswanya. sebagai masukan untuk memperbaiki kinerjanya.

Dalam upaya pemantapan kemampuan mengajar dosen yang diharapkan dapat mengatasi kekurangan dalam proses pembelajaran maka program studi Pendidikan Biologi sangatlah beruntung dapat melaksanakan kegiatan Lesson Study, sehingga dosen dapat melakukan review terhadap kinerjanya yang selanjutnya dapat digunakan Lesson Study, wawasan dosen akan berkembang dan termotivasi untuk selalu berinovasi yang selanjutnya akan menjadi dosen yang lebih profesional. dan usaha yang dilakukan dalam meningkatkan mutu pendidikan menghasilkan calon calon guru yang professional (Muiz, A, dalam Sukirman, 2011: 4). Program Lesson Study merupakan salah satu kulminasi atau muara program yang memberikan kesempatan kepada para dosen khususnya MIPA untuk memantapkan kompetensi pedagogik, kepribadian, profesional dan sosial dalam rangka memperbaiki atau meningkatkan mutu pembelajarannya agar dapat menghasilkan lulusan calon guru atau guru yang bermutu dan lebih baik.

Selain itu dari sisi lain karena dalam kegiatan Lesson Study ini dikembangkan prinsip prinsip kolegalitas dan mutual learning melalui tiga tahapan yaitu merencanakan (plan), melaksanakan (do), dan merefleksi (see) yang berupa kegiatan berkelanjutan. Sehingga dalam kegiatan Lesson Study ini semua dosen dapat belajar dan terlibat langsung dalam tiga kegiatan tersebut (plan, do, and see) secara bersama-sama.

Dalam kegiatan Lesson Study ini juga dapat dikembangkan tingkat profesionalisme dosen karena dilaksanakan secara kolaborasi antara dosen satu dengan yang lainnya berdasarkan prinsip-prinsip kolegalitas (kesejawatan) dan mutual learning (pembelajaran yang saling membantu). Dosen atau peserta yang sudah paham atau memiliki ilmu lebih harus mau berbagi dengan dosen lain yang belum paham, dan sebaliknya dosen yang belum paham harus mau bertanya kepada dosen atau peserta yang sudah paham. Kebersamaan ini terjadi pada 
pembahasan

Pembelajaran

Rencana

(RMP)

Mutu

perangkatnya, seperti media, LKS atau alat pembelajaran, instrument evaluasi, dll serta implementasi RMP di kelas juga kegiatan refleksi yang mendiskusikan kegiatan pembelajaran yang baru saja dilaksanakan berdasarkan hasil observasi, dalam rangka perbaikan RMP dan perbaikan pembelajaran selanjutnya (Muiz, A, dalam Sukirman, 2011: 5).

Aktivitas belajar juga sangat perlu dikembangkan dalam proses pembelajaran karena dengan aktivitas pembelajaran akan lebih bermakna. Sardiman (2011: 20) berpendapat bahwa "belajar adalah berbuat, berbuat untuk mengubah tingkah laku, jadi melakukan kegiatan. Tidak ada belajar kalau tidak ada aktivitas. Aktivitas belajar adalah segenap rangkaian kegiatan atau aktivitas secara sadar yang dilakukan seseorang yang mengakibatkan perubahan dalam dirinya, berupa perubahan pengetahuan atau kemahiran yang sifatnya tergantung pada sedikit banyaknya perubahan. Paul B. Diedrich yang dikutip dalam Nanang Hanafiah dan Cucu Suhana (2010:24) dan Peduk Rintayati dan Sulistya Partomo Putro (2011: 7) menyatakan, aktivitas belajar dibagi ke dalam delapan kelompok, yaitu sebagai berikut: Kegiatan-kegiatan visual (visual activities), Kegiatankegiatan lisan (oral activities), Kegiatan-kegiatan mendengarkan (listening activities), Kegiatankegiatan menulis (writing activities) Kegiatan-kegiatan menggambar (drawing activities), Kegiatankegiatan motorik (motor activities), Kegiatan-kegiatan mental (mental activities), dan Kegiatan-kegiatan emosional (emotional activities)

Berdasarkan fenomena di atas maka yang berperan penting dalam pendidikan tinggi adalah seorang dosen yang profesional, yang mampu merangsang mahasiswa agar selalu belajar dan dosen merupakan motivator dan fasilitator bagi mahasiswa. Dosen harus memberikan motivasi bagi mahasiswanya untuk belajar agar proses belajar mengajarnya berhasil sesuai dengan kurikulum yang berlaku. Mata kuliah Anatomi Tumbuhan merupakan mata kuliah penting yang sarat dengan bahasa Latin dan materi yang cukup padat. Mata kuliah tersebut merupakan mata kuliah prasyarat bagi mata kuliah biologi lainnya antara lain: Biologi sel, Fisiologi Tumbuhan, dan Ekologi Tumbuhan. Dalam mata kuliah ini dibahas tentang struktur dan fungsi organela sel, macammacam jaringan dan fungsinya, serta organologi pada tumbuhan.

Berdasarkan pengalaman pembelajaran pada tahun-tahun akademik sebelumnya, untuk pokok bahasan pembelahan sel dan organologi pada tumbuhan, banyak mahasiswa yang kurang memahami materi sehingga nilai ujian $70 \%$ dibawah 50 atau D. Mereka banyak yang kurang paham terutama untuk perbedaan pembelahan sel secara mitosis dan meiosis, anatomi organ tumbuhan (daun, batang, dan akar) antara tanaman dikotil dengan tanaman monokotil. Berbagai usaha telah dilakukan antara lain, dengan pemberian kuis atau latihan, dengan pendekatan kooperatif, serta dengan pemberian ulangan formatif pada setiap pokok bahasan, namun hasil 
ujian semester masih belum memuaskan dan masih ada beberapa mahasiswa yang mendapat nilai $\mathrm{C}$, dan materi pembelahan sel serta organologi khususnya belum sepenuhnya mereka pahami terutara perbedaan organ monokotil dan dikotil.

Permasalahan disebabkan oleh proses pembelajaran yang masih menggunakan diskusi informasi yang belum banyak melibatkan aktivitas mahasiswa. Materi dibahas secara lepas atau atau sendiri-sendiri untuk pembelahan sel, organ daun, organ batang, dan organ akar baik dikotil maupun monokotil.

Dengan permasalahan tersebut maka perlu adanya solusi penerapan model pembelajaran komparasi. Dalam pendekatan ini akan diterapkan paparan materi pembelahan sel (mitosis dan meiosis) dan organologi tumbuhan disertai konfirmasi materi oleh dosen pengampu dilanjutkan diskusi komparasi materi dan presentasi hasil diskusi. Pada model pembelajaran komparasi ini mengabungkan pembelajaran behavioris, kognitif, dan konstruktif dalam suatu kerangka pemikiran. Model komparasi ini tidak mengkotak-kotakan secara tegas untuk kemudian memilih salah satu secara terpisah, tetapi menentukan kombinasi yang tepat untuk aplikasi yang sesuai dengan keadaan dan konteks pembelajaran (Zuh, MR, 2012 dan Nuryani Y. Rustaman. 2000). Dengan pembelajaran model komparasi ini maka diharapkan mahasiswa atau peserta didik akan berlatih, berfikir, menyelesaikan masalah,dan membentuk konsep sendiri beserta teman kelompoknya, yang akhirnya dapat meningkatkan prestasi belajarnya. Adapun tujuan yang akan dicapai dari penelitian ini adalah untuk meningkatkan aktivitas dan hasil belajar mahasiswa pada mata kuliah Anatomi Tumbuhan melalui model pembelajaran komparasi.

\section{METODE}

Penelitian PTK berbasis Lesson Study ini dilakukan di program studi Pendidikan Biologi, mulai bulan November 2013 sampai bulan April 2014 dengan 4 siklus. Adapun subyek penelitiannya adalah mahasiswa program studi pendidikan Biologi angkatan tahun 2012 (semester III tahun akademik 2013/2014) sebanyak 24 orang dan tim dosen mata kuliah Anatomi Tumbuhan yang terdiri 3 orang.

Sumber data dalam penelitian tindakan kelas ini adalah; mahasiswa yang mengambil mata kuliah Anatomi Tumbuhan yang berupa nilai post tes, serta hasil pengamatan terhadap aktivitas saat berdiskusi dan mengerjakan tugas.

Target atau hasil yang diharapkan harus dicapai dari kegiatan ini adalah perbaikan atau peningkatan kualitas pembelajaran pada mata kuliah Anatomi Tumbuhan, dengan indikator:

1. Untuk aktivitas belajar mahasiswa:

a. keaktifan dalam presentasi

b. keaktifan dalam mengajukan pendapat

c. keaktifan dalam bertanya

d. keaktifan dalam menjawab pertanyaan

e. keaktifan mendengarkan pendapat orang lain 
2. Untuk hasil belajar mahasiswa

a. Nilai ulangan / tes formatif

Teknik analisis data dengan diskriptif komparatif, membandingkan hasil belajar dan aktivitas belajar siklus I sampai dengan siklus IV

\section{HASIL DAN PEMBAHASAN}

Kondisi awal pelaksanaan pembelajaran matakuliah Anatomi Tumbuhan, mahasiswa semester 3 regular aktivitasnya sangat rendah, mereka dalam kerja kelompok banyak yang apatis tak peduli dengan tugas dan tanggungjawab, mereka yang prestasinya rendah kadang banyak yang tidak ikut dalam melaksanakan tugas. Prestasi belajar untuk Kompetensi Dasar tentang Sel Tumbuhan dan Jaringan $70 \%$ memperoleh nilai $\mathrm{C}$ dari 24 orang pengambil mata kuliah.
Dengan kondisi tersebut di atas kemudian strategi pembelajaran diubah dengan pendekatan pembelajaran komparasi. Namun tetap menggunakan pendekatan kooperatif. Dibentuk kelompok belajar dan tiap kelompok terdiri 3-4 orang. Tiap kelompok ada anggota dari mahasiswa pintar dan tidak pintar. Selain itu untuk mengetahui ketuntasan belajar pada tiap kompetensi dasar atau pokok bahasan diberikan pos test. Dengan penerapan strategi pembelajaran tersebut ternyata dalam 4 siklus terjadi peningkatan dalam aktivitas belajar dan hasil belajar. Adapun perubahan nilai nilai tersebut dapat dilihat dalam Tabel 1 yang merupakan hasil pelaksanaan Siklus I, II, III, dan IV.

Tabel 1. Perbandingan hasil siklus I, II, III dan IV.

\begin{tabular}{ccccccc}
\hline Siklus & $\begin{array}{c}\text { Yang } \\
\text { Aktif } \\
\text { berdiskusi }\end{array}$ & $\begin{array}{c}\text { Nilai } \\
\text { Aktivitas } \\
\text { Diskusi }\end{array}$ & $\begin{array}{c}\text { Nilai } \\
\text { Tertinggi }\end{array}$ & $\begin{array}{c}\text { Nilai } \\
\text { Terendah }\end{array}$ & $\begin{array}{c}\text { Rata-rata } \\
\text { Nilai } \\
\text { Postest }\end{array}$ & $\begin{array}{c}\text { Peningkatan } \\
\text { Prestasi }\end{array}$ \\
\hline I & 11 & Cukup Aktif & 4,0 & 2,8 & $3,47 / \mathrm{B}$ & - \\
\hline II & 14 & Cukup Aktif & 4,0 & 2.3 & $3,72 / \mathrm{A}$ & $7 \%$ \\
\hline III & 19 & Cukup Aktif & 4,0 & 3,2 & $3,73 / \mathrm{A}$ & $0,3 \%$ \\
\hline IV & 20 & Aktif & 4,0 & 3,6 & $3,85 / \mathrm{A}$ & $3 \%$ \\
\hline
\end{tabular}

Kenaikan hasil pada siklus I, II, III, dan IV disebabkan dalam kegiatan pembelajaran ini diterapkan pendekatan komparasi dan kooperatif. Dimana model pembelajaran komparasi terjadi penggabungan pembelajaran behavioris, kognitif, dan konstruktif dalam suatu kerangka pemikiran. Model komparasi ini tidak mengkotak-kotakkan secara tegas untuk kemudian memilih salah satu secara terpisah, tetapi menentukan kombinasi yang tepat untuk aplikasi yang sesuai dengan keadaan dan konteks pembelajaran (Zuh, MR, 2012). Dan paham kontruktivisme yang mengasumsikan bahwa mahasiswa akan mudah mengkonstruksi pengetahuannya, lebih mudah menemukan dan memahami pemecahan konsep konsep yang sulit jika mereka saling mendiskusikannya dengan temannya (Zuh, MR, 2012). Penerapan model 
pembelajaran komparasi dan kooperatif (pembelajaran konstruktif) memang sangat relevan untuk meningkatkan aktivitas belajar mahasiswa yang didasarkan pada pemanfaatan pengaruh teman sebaya dalam memahami sesuatu permasalahan yang bersama-sama sedang dihadapi (Zuh, MR, 2012 dan Nuryani Y. Rustaman. 2000).

Dengan pendekatan komparasi yang pada intinya membandingkan dua materi yang berbeda dan didukung pendekatan kooperatif yang mendorong dan memberi kesempatan kepada peserta didik untuk terampil berkomunikasi dan membentuk konsep baru bersama temannya maka wajarlah jika terjadi peningkatan aktivitas dan hasil belajarnya. Karena dalam belajar juga diperlukan adanya aktivitas. Tanpa aktivitas kegiatan belajar tidak mungkin berlangsung dengan baik. Sardiman (2011: 20) berpendapat bahwa "belajar adalah berbuat, berbuat untuk mengubah tingkah laku, jadi melakukan kegiatan. Tidak ada belajar kalau tidak ada aktivitas. Aktivitas belajar adalah segenap rangkaian kegiatan atau aktivitas secara sadar yang dilakukan seseorang yang mengakibatkan perubahan dalam dirinya, berupa perubahan pengetahuan atau kemahiran yang sifatnya tergantung pada sedikit banyaknya perubahan. Lebih lanjut Sardiman (2011: 20) mengatakan, aktivitas dalam proses belajar mengajar merupakan rangkaian kegiatan yang meliputi keaktifan siswa dalam mengikuti pelajaran, bertanya hal yang belum jelas, mencatat, mendengar, berfikir, membaca, dan segala kegiatan yang menunjang prestasi belajar.

\section{SIMPULAN DAN SARAN}

Dari penelitian yang telah dilaksanakan dapat diambil kesimpulan bahwa:

1. Pembelajaran Komparasi dapat meningkatkan aktivitas belajar mahasiswa pada mata kuliah Anatomi Tumbuhan (siklus I sampai III kategori cukup aktif dan siklus IV kategori aktif)

2. Pembelajaran Komparasi dapat meningkatkan hasil belajar mahasiswa pada mata kuliah Anatomi Tumbuhan (hasil belajar dari siklus I sampai IV semakin meningkat, mulai 3,$47 ; 3,72 ; 3,73$; dan 3,85)

\section{DAFTAR PUSTAKA}

Djohar. (1985). Sejarah Pendidikan Sains dan Implikasinya bagi Pengembangan Konsep Belajar Mengajar IPA. Cakrawala Pendidikan. Vol.4, No. 2.

Hanafiah, Nanang \& Cucu Suhana. (2010). Konsep Strategi Pembelajaran. Bandung: Refika Aditama.

Nuryani, Y. Rustaman. (2000). Kontruktivisme dan Pembelajaran IPA/Biologi. Makalah Seminar Lokakarya Guru-guru IPA SLTP Sekolah Swasta di Bandung.

Rintayati, P. \& Sulistya Partomo Putro. (2011). Meningkatkan Aktivitas Belajar (Active Learning) Siswa Berkarakter 
Peningkatan Aktivitas dan Hasil Belajar 31

Cerdas Dengan Pendekatan Sains Teknologi (STM). Journal Didaktika Dwija Indria, Vol. 1, No. 2.

Sardiman. (2011). Interaksi dan Motivasi Belajar Mengajar. Jakarta: Rajawali.

Sukirman. (2011). Workshop dan Sosialisasi Lesson Study: Upaya Meningkatkan Mutu Perkuliahan Pada Perguruan Tinggi Melalui Lesson Studi. Sukoharjo: FKIP Universitas Veteran Bangun Nusantara.
Zuh, MR. (2012). Pengertian Desain Pembelajaran. Diakses dari http://zuhairistain.blogspot.co $\mathrm{m} / 2009 / 04 /$ pengertiandesainpe mbelajaran_16.html. 